\title{
Depoimento
}

\section{2 ou 3 coisas que eu sei sobre ela}

\section{Sabrina Sedlmayer, UFMG}

1. Biblioteca. Talvez todo professor, depois de muitos anos em sala de aula, seja capaz de enumerar os livros essenciais utilizando apenas os cinco dedos de uma das suas mãos. Os grandes poetas facilmente descreveriam. Entre estes, há um que a Jeanne Marie ainda não leu, e só por isso, creio, não se encontra em sua biblioteca. Num de seus poemas, diz o seguinte:

Amo devagar os amigos que são tristes com cinco dedos de cada lado.

Os amigos que enlouquecem e estão sentados, fechando os olhos,

com os livros atrás a arder por toda a eternidade.

Não os chamo, eles voltam-se profundamente

dentro do fogo.

-Temos um talento doloroso e obscuro.

Construímos um lugar de silêncio.

De paixão.

Herberto Helder, escritor português, denomina de amigos os autores que o formam. São as vozes comunicantes que o empurram para a escrita. Nessa cena, marcadamente ética e afetiva, os amigos silenciam para que a sua voz apareça. Continuam, entretanto, presentes, em movimento, pois estão na combustão do processo criativo, ardendo, são parte do fogo. Algo que Hölderlin há tempos sentenciara: "o que fica os poetas fundam." Ou que Montaigne, nos Essais, também tenta explicar dizendo como a amizade é um amor sem por quê, cuja resposta, a única possível para justificar a sua existência seria: "Porque era ele; porque era eu."

Tudo isso me faz atrelar Jeanne Marie a certos livros e a tentar compor sua mãobiblioteca. Sempre imaginei que os seus cinco amigos seriam:
1) a Odisseia
2) Das Passagen Werk
3) a Bíblia
4) a Recherche
5) O Capital

Por mais que nós, leitores brasileiros dos seus textos, acreditemos que o seu nome se confunde indistintamente com o de Walter Benjamin e que este autor deveria constar em sua mão inteira e em cada um dos seus dedos estar alojada uma das suas obras, há algo nessa pensadora, formada em Filosofia numa Paris cujas "estruturas" saíram das universidades para lutarem pelas ruas, num mapa além-Sorbonne, que a faz ser defensora do pensamento materialista atrelado a uma sensível e tensa leitura da estética. Gagnebin lê a obra do filósofo berlinense em sua densidade política e literária. E acho que é justamente aí que entra a potência redundante - o estilo, como bem caracteriza Starobinski - da sua escrita. Jeanne Marie é tradutora (no sentido largo da palavra) da obra de muitos. Seus prefácios e ensaios iluminam. As suas

Cadernos Benjaminianos, Número especial, Belo Horizonte, 2013, página 8-10 
traduções buscam o termo terno, sem impostura e malabarismos linguísticos. Há uma elegância na simplicidade dessas traduções que fazem com que todos se sintam mais perto dos autores comentados e traduzidos. Ocorre-me, agora, uma paráfrase de uma famosa epígrafe de Freud: quando a lemos, o escuro se torna claro.

Bem se sabe que, para chegar a esse poder de laconismo e precisão, centenas de outros livros foram lidos. Mas o que faz restar alguns, cinco talvez, depois de anos e anos de teses orientadas, relatórios escritos, pareceres concluídos, artigos enviados, emails respondidos, jornais e revistas interpretados?

Sempre desconfiei que a identificação era uma perspectiva do amor e da partilha. E que nem sempre é a máscara de Narciso que nós faz escolher este ou aquele livro. Homero, Benjamin, os autores anônimos da Bíblia, Proust, Marx...interrogam Jeanne Marie até hoje.

Acho que isso é uma coisa que eu sei sobre ela.

2. Figos frescos. A lembrança e o seu pólo oposto, o esquecimento, perpassam a obra de Gagnebin como um ritornello. Das musas enlouquecidas da Grécia Antiga até o silêncio constrangedor da produção intelectual brasileira sobre os anos de chumbo, na ditadura militar, ou do massacre da Shoah, a memória involuntária em Proust, todos esses tópicos estão presentes em seus textos com precisa e incômoda insistência, no sentido mais pontual da palavra "tarefa", empregada por Benjamin.

Tarefa sem fim, a de falar da mémoria. Como o tema da comida.

Nunca confessei para a minha amiga Jane (é assim que eu a chamo) que entre todos os textos de Benjamin, o intitulado "Figos frescos" é um dos meus prediletos. Já cozinhei diversas vezes para ela. Nunca próxima das panelas ou comedida nas cadeiras dos colóquios sem fim, relacionei este texto ao tema da memória. Tentarei fazer agora.

Sabe-se que há uma voracidade bulímica em quem frequenta os livros e em quem gosta de comer bem. E com Benjamin não é diferente:

Comer, isto significa antes de tudo: comer radicalmente. Não há dúvidas de que isso alcança mais profundamente a coisa devorada que o prazer. Por exemplo, quando alguém dá uma dentada na mortadela como se fosse pão, se chafurda no melão como numa almofada, lambe caviar de papel farfalhante e sobre uma cuia de queijo Edam se esquece de tudo o mais que existe na Terra para comer. - Como foi que eu soube disso pela primeira vez ${ }^{1}$

O autor encontrava-se em Nápoles, certa vez, quando provou uma iguaria sem moderação: figos frescos. Os frutos, lembra ele, eram belos, pretos, azuis, verdeclaros, violetas e marrons e se encontravam expostos na rua. Num impulso, porque encontrava-se em pleno ócio da flânerie, comprou-os. Mas a vendedora não tinha papel para embrulhá-los. Benjamin guarda-os, então, nos bolsos da calça. Tenta, sofregadamente, comê-los, para que acabem rápido. Nesse tempo, o que antes eram apenas frutas, passam a ser uma carga excessiva, pesada, de difícil transporte, incômoda mesmo, e ocorre a tranformação daquilo que ele mais desprezava: o prazer vira hábito, o amor se transmuta em ódio.

Mas, para mim, a beleza deste fragmento é que a contingência sela o destino: "quando arranquei o último figo do fundo do meu bolso, nele estava colada a

Cadernos Benjaminianos, Número especial, Belo Horizonte, 2013, página 8-10 
carta...Também ela devia ser sacrificada à grande limpeza. Tomei-a e rasguei-a em mil pedaços."

A carta não chega ao seu destinatário. E o curioso desse quase conto é que se trata de uma recuperação de uma lembrança. Ao lado dele, constam outros, o "Café creme", "Falerno e bacalhau", "Borscht", "Pranzo caprese", "Omelete de amoras", que também focalizam o tema da comida, nessas "imagens do pensamento". E em todos a comida está colada à lembrança de um tempo vivido e perdido. A força da madeleine permeia os escritos, mas não os esgota. Um lirismo acoplado à falta de jeito do comensal (o corcundinha que ele era) encontram-se mesclados também.

Quem já teve a alegria de escutar a Jeanne Marie falar, sabe que ela pensa com delicadeza e exprime radicalmente. Possuí uma sinceridade radical. A polidez, as máscaras sociais com seus patéticos charmes e lisuras não fazem parte dessa pensadora que também ama comer bem. Desconheço, ainda, se ela ama figos frescos como eu.

Isso eu ainda terei que aprender com ela.

Belo Horizonte, Verão 2013

\section{Referências}

BENJAMIN, Walter. Figos frescos. In: BENJAMIN, Walter. Rua de mão única: ensaios sobre literatura e história da cultura. $2^{\mathrm{a}}$ ed., trad. Rubens Rodrigues Torres Filho e José Carlos Martins Barbosa, São Paulo: Brasiliense, 1987, p. 213. - (Obras escolhidas; v. 2)

\section{Notas}

${ }^{1}$ BENJAMIN. Figos frescos, p. 213.

2 BENJAMIN. Figos frescos, p. 214. 